\title{
VALVE MORPHOLOGY OF THE BENTHIC DIATOM Fallacia marnieri (Manguin) Witkowski (SELLAPHORACEAE - BACILLARIOPHYTA)
}

\author{
PROCOPIAK, L. K. and FERNANDES, L. F. \\ Departamento de Botânica, Setor de Ciências Biológicas, Universidade Federal do Paraná, Centro Politécnico, \\ Jardim das Américas, C.P. 19031, CEP 81531-970, Curitiba, Paraná, Brazil \\ Correspondence to: Luciano F. Fernandes, Departamento de Botânica, Setor de Ciências Biológicas, \\ Universidade Federal do Paraná, Centro Politécnico, Jardim das Américas, C.P. 19031, CEP 81531-970, \\ Curitiba, Paraná, Brazil, e-mail: lucfel@bio.ufpr.br \\ Received February 25, 2002 - Accepted August 27, 2002 - Distributed February 28, 2003
}

(With 12 figures)

\begin{abstract}
The genus Fallacia Stickle \& Mann includes naviculoid birraphid diatoms with H-like plastids, valves with uniseriate striae and covered by porous conopea, rounded areolae occluded by hymens, and depressed hyaline lyriform area characterizing the valvar surface. The species Fallacia marnieri was found in samples collected in King George Island, Antarctic Peninsula, on which an electron microscopy study and literature revision were carried out. From this investigation, we found that since Fallacia marnieri has the diagnostic structures of the genus, its recent inclusion in Fallacia is justified. The species was found on rocks of an intertidal region, and seems to be endemic in cold regions, as indicated in the literature.
\end{abstract}

Key words: diatom, Fallacia marnieri, Bacillariophyta, benthic, microphytobenthos, Antarctic.

\section{RESUMO}

\section{Morfologia da valva da diatomácea bêntica Fallacia marnieri (Manguin) Witkowski (Sellaphoraceae - Bacillariophyta)}

O gênero Fallacia Stickle \& Mann inclui diatomáceas naviculóides birrafídeas contendo plastídeos em "H", valvas com estrias geralmente unisseriadas cobertas externamente por conopea porosa, aréolas arredondadas ocluídas por hímenes e área hialina liriforme em canal. A espécie Fallacia marnieri foi encontrada em amostras coletadas na Ilha Rei George, Península Antártica, e estudos em microscopia eletrônica de varredura e revisão bibliográfica da mesma foram realizados. Com base nessa investigação, observamos que sua transferência para o gênero Fallacia foi justificada, uma vez que essa diatomácea apresenta estruturas diagnósticas de Fallacia. A espécie foi encontrada sobre rochas de região entremarés na Antártica, e parece ser endêmica de regiões frias, conforme mencionado na literatura.

Palavras-chave: diatomácea, Fallacia marnieri, Bacillariophyta, bêntica, Antártica.

\section{INTRODUCTION}

Many species with uncertain affinities have been assigned to the genus Navicula Bory, 1822, one of the largest among the diatoms, leading to considerable taxonomic problems. Indeed, the genus has became a catchall of species diversely related. Even the nomenclatural type of this important genus has just recently been designated by Patrick (1959), after much confusion in the literature (Cox, 1979). Later, its circumscription was elegantly reviewed by Cox (1979), who also provided an amended description of the genus. After the development of electron microscopy 
techniques for morphological studies of these naviculoid biraphid diatoms, many changes in the systematics of Navicula have been proposed. These include the creation of new genera, a necessary step to improve the circumscription of Navicula as well as to accommodate groups having closer affinities with each other and, at the same time, quite different from those having the diagnostic features of Navicula sensu Cox (1979). In some cases, the adequacy of this procedure has been a matter of controversy among diatomists (Kociolek, 1996, 1998; Round, 1996, 1997).

The genus Fallacia Stickle \& Mann (in Round et al., 1990) has resulted from one of the initiatives for improving the systematics of Navicula, which removed some taxa belonging to the Lyratae Cleve section to Fallacia (Round et al., 1990; Witkowski, 1991, 1993). The genus was placed in the family Sellaphoraceae, which includes Caponea, Rossia, and Sellaphora (Round et al., 1990). Its main characteristics are lanceolate to elliptic valves with flat surface, curving near the mantle margin, areolae occluded by hymenes and forming unisseriate striae, and the presence of a conopea covering the valvar surface partially or totally, including the hyaline lyriform area, which is sunken on the external surface. The raphe system is double, having a thickened raphe sternum. The internal central endings of the raphe are turned to the primary side of the valve, and the external ones are straight and expanded, with terminal fissures conspicuously bent or hook-like. The genus Lyrella N.I. Karajeva (Family Lyrellaceae) is closely related to Fallacia when observed under light microscopy but, under an electron microscope, it can be noted that the former genus lacks conopea, and its lyriform area is continuous in relation to the valvar surface.

In this report, we studied the Antarctic diatom Fallacia marnieri (Manguin) Witkowski, 2000 under a scanning electron microscope in order to verify the existence of typical features of Fallacia, as advocated by Witkowski et al. (2000) based on light microscope examination.

\section{MATERIAL AND METHODS}

Samples containing the studied material were collected in November-December 1994 in Admiralty
Bay $\left(62^{\circ} 05^{\prime} S\right.$ and $\left.58^{\circ} 35^{\prime} \mathrm{W}\right)$, facing the Brazilian Antarctic Station "Comandante Ferraz", during the XIII Brazilian Antarctic Program (PROANTAR XIII). The material was obtained from intertidal and sublitoral zones through autonomous diving (SCUBA) and removed by using a fine-bristled brush. For cleaning the frustules, the technique of Hasle \& Fryxell (1970) was used, with Naphrax as the mounting medium for permanent slides. Analyses of valves by light microscopy (LM) were made by using an Olympus BX40 photomicroscope. A Phillips XL30 scanning electron microscope at an acceleration voltage of $10-20 \mathrm{kV}$ was used for examinations in electron microscopy (SEM). As the species was rare among the samples, aliquots of cleaned material were dropped on several microscope slides, left to evaporate and, soon after, examined under light microscopy. The valves found of $F$. marnieri were then transferred to alumnium stubs by using a delicate acupuncture needle and gently placing each valve on a carbon tape.

\section{OBSERVATIONS}

\section{Description of the species}

Fallacia marnieri (Manguin) Witkowski, 2000

Basionym: Navicula marnieri Manguin, 1957, Revue Algologique, no 3, Nov. 1957, p. 127 , Figs. 35a and 35b, as N. marnieri.

Synonyms: Navicula diploneiformis Hustedt, 1958; Navicula marnieri Manguin, 1960; Diploneis reichardtii var. tschuktschorum (Cleve) Heiden (Cardinal et al., 1984, their Figs. 50, 51, 53).

Literature: Cleve (1883):472, Pl. 37, Fig. 48; Manguin (1957):127-128, Pl. 5, Figs. 35a-b; Hustedt (1927-66):367-369, Fig. 1458a-b; Hustedt (1958):147, Pl. 9, Fig. 100; Manguin (1960):314, Pl. 15, Fig. 180; Cardinal et al. (1984):377, Figs. 50-51, 53; Witkowski et al. (2000):207, Pl. 71, Figs. 1-3.

The valves are elliptic with flat valvar surface, curving near the margin (Figs. 2-4, 9). Dimensions are $16.4 \mu \mathrm{m}$ to $26.2 \mu \mathrm{m}$ of apical axis, $7.9 \mu \mathrm{m}$ to $10.6 \mu \mathrm{m}$ of transapical axis and 7-10 striae in 10 $\mu \mathrm{m}$ (15 valves measured). Striae are parallel only at the center, gradually becoming radiate towards the apices, and sharply spaced with respect to each other (Figs. 3, 7), also illustrated in Manguin's 
original drawings (Fig. 1). The areolae are round, occluded by hymenes (Figs. 7, 8). Raphe system is straight. On the outer side, the central endings are slightly expanded (Fig. 9), and the terminal ones are hook-like (Fig. 10), deflected to the same side. Internally, both the central and terminal endings are straight (Figs. 5-7), and the latter are slightly raised in relation to the valve face (Fig. 6). A well-developed conopea seems to reach the valvar margin (Figs. 11-12). Under SEM, the valvar surface is covered by the siliceous membrane of the conopea, masking other structures like striae and areolae, the lyriform area, and a portion of the raphe system (Figs. 9, 12). On the other hand, under LM one can observe these structures, but not the conopea (Figs. 2-4). Viewed internally, the areolae and the raphe system are evident (Fig. 7). The lyriform area is narrow, showing a constriction in the central region of the valve (Figs. 3-5). Besides, it is sunk within the external surface to form a canal-like structure, which is seen as a projection on the internal side (Fig. 5). The best picture we got to elucidate the canal structure shows a fractured valve making visible a small opening (Fig. 8). Between the lyriform area and the raphe sternum there is a smooth siliceous layer (Fig. 5), i.e., lacking areolae though they are common in another species within the genus (Round et al.,
1990; Witkowski, 1991, 1993). All the valves we observed had 1-3 perforations, similar to areolae in that region (Figs. 3, 5-7).

\section{Nomenclature}

Manguin (1957) originally described the species Navicula marnieri, dedicated to the botanist M. J. Marnier-Lapostolle, found in Antarctica. Almost at the same time, Hustedt (1958) described the same species under the name Navicula diploneiformis Hustedt, also found in Antarctica, in the intestine of Salpa fusiformis. Not much later, Hustedt (1927-66) claimed that his work of 1958 appeared soon after that of Manguin due to press problems, but accepted the precedence of Manguin, including that species as a later synonym of $N$. marnieri. Surprisingly, Manguin (1960) redescribed the same species three years later, in a more detailed way than the first description by Manguin (1957).

The reasons for this procedure are unclear, as the publication of 1957 is valid according to ICBN. Van Landinghan (1975) also considered all these names synonyms of $N$. marnieri, correcting the specific epithet for "marnieri". Cardinal et al. (1984) illustrated in their Figs. 50,51 , and 53 three valves which they named Diploneis reichardtii var. tschuktschorum (Cleve) Heiden in Heiden et Kolbe.

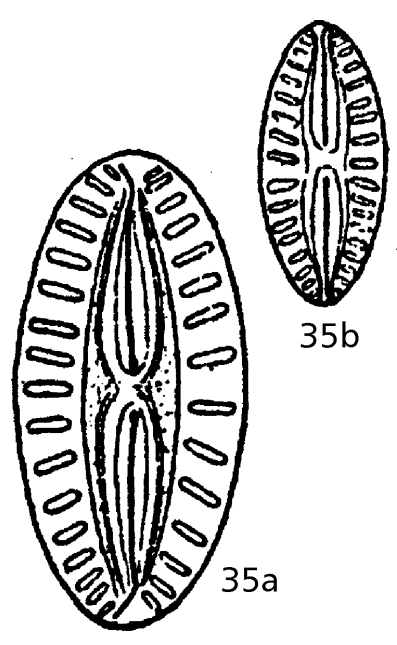

Fig. 1 - Fallacia marnieri. Original drawings of Manguin (1957). 


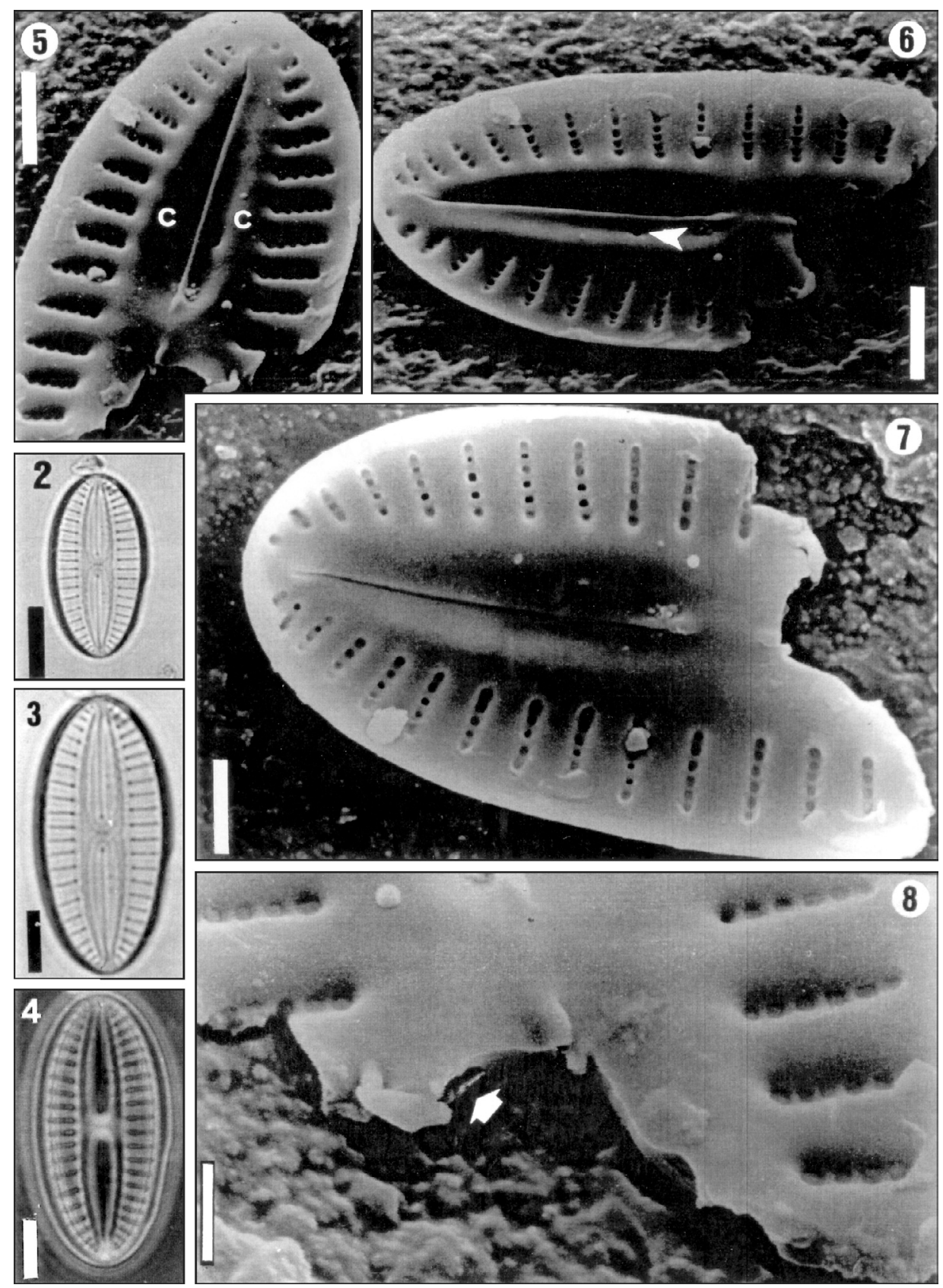

Figs. 2-8 - Fallacia marnieri, Elephant Island, Antarctic Peninsula. Figs. 2-4 - LM, cleaned valves. Figs. 5-8 - SEM, internal views. Fig. $2-$ Scale bar $=10 \mu \mathrm{m}$. Figs. 3-4 - Note lyriform area and two perforations in each of the hyaline areas between the raphe and the lyriform area. Scale bar $=5 \mu \mathrm{m}$. Figs. 5-6 - Valve tilt $30^{\circ}$ in different positions, showing the raphe branch ending in incipient helictoglossa. Lyriform area is well marked, projecting from the siliceous layer to form the canal (C). Note thickened ribs separating striae. Scale bar $=2.5 \mu \mathrm{m}$. Fig. $7-$ General view of valve, elucidating striae pattern and number of areolae per striae. Scale bar $=2 \mu \mathrm{m}$. Fig. 8- Broken valve, tilt $30^{\circ}$. The canal of lyriform area is showed (arrow). Scale bar $=1 \mu \mathrm{m}$. 

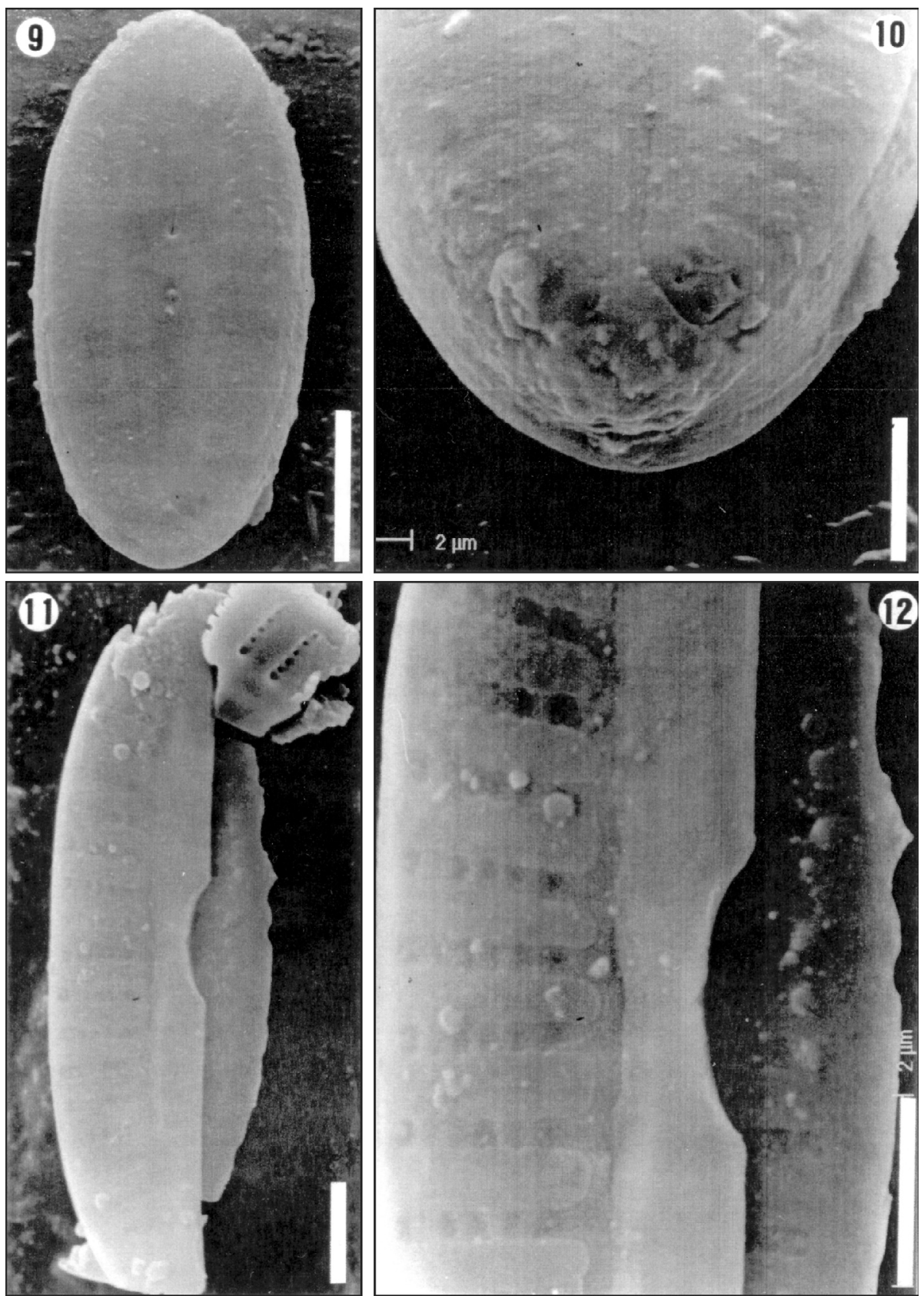

Figs. 9-12 - Fallacia marnieri, Elephant Island, Antarctic Peninsula. SEM, external views. Fig. 9 - General view of frustule. Conopea recovers the valvar surface, hiding other ornamentations. The lyriform area is just discernible (arrows). Scale bar $=5 \mu \mathrm{m}$. Fig. 10 - Detail of apex, showing distal ending of the raphe, hook-like. Scale bar $=2 \mu \mathrm{m}$. Fig. $11-$ Broken valve across the apical axis. Scale bar $=2.5 \mu \mathrm{m}$. Fig. $12-$ Same valve enlarged to show the delicate conopea recovering areolae. Scale bar $=2 \mu \mathrm{m}$. 
After analyzing those figures, we concluded that the valves actually belong to Fallacia marnieri. Recently, Witkowski et al. (2000) transferred $N$. marnieri to Fallacia marnieri based on light microscopy observations. Finally, an important note must be made here. Cleve (1883) described the species Navicula tschuktschorum which is very similar to F. marnieri. Conversely, after examining the description and figure given by Cleve, we suspect the species actually is the same as $F$. marnieri. Its dimensions are $10 \mu \mathrm{m}$ apical axis, $6.5 \mu \mathrm{m}$ transapical axis, and 13 striae in $10 \mu \mathrm{m}$ (Cleve, 1883). If this assumption is true, $N$. tschuktschorum has priority over F. marnieri, and this specific name is a later synonym of $N$. tschuktschorum.

\section{DISCUSSION}

Hustedt and Manguin had already noticed that $F$. marnieri presented characteristics (like hyaline area and type of areolae) that allowed for its placement in the Lyratae section. Indeed, they also pointed out other features that drew F. marineri closer to Diploneis "par les branchés du raphé placées dans un sillon semblebles aux cornes si characterístiques des représentants de ce genre" (Manguin, 1960). These are structures that distinguish " $N$. marnieri" from another taxa of Navicula. The investigations carried out in the present work indicated the presence of diagnostic characters of Fallacia, like areolae with hymenes and well-developed conopea, allowing us to confirm the allocation of N. marnieri in Fallacia, as proposed by Witkowski et al. (2000) based on light microscope observations.

The dimensions found in our material are similar or larger than those found in previous publications: $15-19 \mu \mathrm{m}$ apical axis, $6.5-8 \mu \mathrm{m}$ transapical axis, and 7-9 striae in $10 \mu \mathrm{m}$ in Manguin (1957, 1960); $14 \mu \mathrm{m}$ apical axis and $6.5 \mu \mathrm{m}$ transapical axis in Hustedt (1958 corrected in Simonsen, 1987); 14-19 $\mu \mathrm{m}$ apical axis, $6.5 \mu \mathrm{m}$ transapical axis, and 7-8 striae in $10 \mu \mathrm{m}$ in Hustedt (1927-66); 11-24 $\mu \mathrm{m}$ apical axis, 6-11 $\mu \mathrm{m}$ transapical axis, and 9-12 striae in $10 \mu \mathrm{m}$ in Cardinal et al. (1984); and 11-24 $\mu \mathrm{m}$ apical axis, 6$11 \mu \mathrm{m}$ transapical axis and 7-12 striae in $10 \mu \mathrm{m}$ in Witkowski et al. (2000).

F. marnieri is similar to F. florinae (Moeller) Witkowski (=Navicula florinae), but the latter has a larger number of striae in the valvar surface, the hyaline area is more expanded and lacks constriction, and the conopea has expansions similar to fingers, not reaching the valvar margin (Witkowski, 1993). In F. marnieri, the conopea is regular and well developed, recovering the entire valvar surface. Additionally, F. marnieri has a smooth siliceous layer between the lyriform area and the raphe sternum, which is absent in $F$. florinae and many other related species (Hustedt, 192766, within Section Lyratae; Round et al., 1990; Witkowsky, 1991, 1993).

According to Hustedt (1927-66), this diatom is a marine species endemic in Antarctica. Hustedt (1958) found it there in the intestine of Salpa fusiformis. Manguin (1960) collected N. marnieri in depths of from 20 to 50 meters. We found the species on intertidal rocks of King George Island, Admiralty Bay, facing the Brazilian Antarctic Station. Other authors have found their specimens in cold northern seas, like the Baltic, and off the Quebec coasts (Cardinal et al., 1984) and the Baltic Sea (Witkowski et al., 2000). Other species of Fallacia have occurred in sandy or muddy sediments, a common habitat of the genus (Hustedt, 1955; Round et al., 1990; Witkowski, 1991, 1993), including the mangrove areas of Southern Brazil (Fernandes et al., 1990; Felício-Fernandes \& Souza-Mosimann, 1994; Felício-Fernandes, 1996).

Acknowledgments — We thank Dr. Daura R. E. Stoffella (Center of Electron Microscopy/UFPR) and Paulo Bryxel (Laboratory of Electron Microscopy/LACTEC) for allowing the unrestricted use of SEM and for their patient assistance. The crew of NaApOc. Ary Rongel/Brazilian Navy was always ready to aid with the sampling and promote integration between researchers and crewmembers. Special thanks go to the military SCUBA divers who collected infralitoral samples. Prof. William Rodrigues (Department of Botany/UFPR) provided valuable information related to nomenclature. This work was made possible due to a contract between the UFPR and the Institute for Technology and Development/LACTEC-Paraná. It was supported by CNPq/PROANTAR, proc. N. 670001/93-7, with a fellowship for L. K. P., and by Centro de Estudos do Mar/ UFPR. Dr. Marines Garcia (UNIVALI/Cttmar) kindly sent some related papers.

\section{REFERENCES}

CARDINAL, A., POULIN, M. \& BÉRARD-THERRIAULT, L., 1984, Les diatomées benthiques de substrates durs des eaux marines et saumâtres du Québec 4. Naviculales, Naviculaceae (à l'exclusion des genres Navicula, Donkinia, Gyrosigma et pleurosigma). Naturaliste Canadien (Rev. Ecol. Syst.), 111: 369-394. 
COX, E. J., 1979, Taxonomic studies on the diatom genus Navicula Bory: the typification of the genus. Bacillaria, 2: 137-153.

FELÍCIO-FERNANDES, G. \& SOUZA-MOSIMANN, R. M., 1994, Diatomáceas no sedimento do manguezal de Itacorubi, Florianópolis, Santa Catarina, Brasil. Insula, 23: $149-215$.

FELÍCIO-FERNANDES, G., 1996, Diatomáceas do rio Tavares, manguezal do rio Tavares, Santa Catarina, Brasil. II. Pennatae. Insula, 25: 69-192.

FERNANDES, L. F., SOUZA-MOSIMANN, R. M. \& FELÍCIO-FERNANDES, G., 1990, Diatomáceas (Bacillariophyceae) do rio Ratones, Florianópolis, Santa Catarina, Brasil. I. Baixo curso e estuário. Insula, 20: 11112.

HASLE, G. R. \& FRYXELL, G. A., 1970, Diatoms: cleaning and mounting for light and electron microscopy. Trans. American Microsc. Soc., 89(4): 469-474.

HUSTEDT, F., 1955, Marine littoral diatoms of Beaufort, North Carolina. Duke University Press, North Carolina, 67p.

HUSTEDT, F., 1958, Diatomeen aus der Antarktis und dem Südatlantik. In: Sonderdruck aus Deutsche Antarktische Expedition 1938/39. Band II, Geographisch-Kartographische Anstalt, Mundus, Hamburg, 103p. + Pls. 3-13.

HUSTEDT, F., 1927-1966, Die Kieselalgen Deutschlands, Österreichs und der Schweiz mit Berücksichtigung der übrigen Ländern Europas sowie der angrenzenden Meeresgebite. In: L. Rabenhorst Kryptogamenflora. Otto Koeltz Science Publishers, Berlin, 7(3): 1-816.

KOCIOLEK, J. P., 1996, Taxonomic instability and the creation of Naviculadicta Lange-Bertalot in LangeBertalot \& Moser, a new catch-all genus of diatoms. Diatom Res., 11(1): 219-222.
KOCIOLEK, J. P., 1998, Does each genus of diatoms have at least one unique feature? A reply to Round. Diatom Res., 13(1): 177-179.

MANGUIN, E., 1957, Premier Inventaire des Diatomées de la Terre Adélie Antarctique. Espéces nouvelles. Revue Algologique, 3: 111-134, 7 pls.

MANGUIN, E., 1960, Les Diatomées de La Terre Adélie Campagne du "Commandant Charcot" 1949-1950. Ann. Desc. Nat. Bot., 12: 225-363.

PATRICK, R., 1959, New species and nomenclatural changes in the genus Navicula (Bacillariophyceae). Proc. Acad. Nat. Sci. Philad., 111: 91-108.

ROUND, F. E., 1996, What characters define diatom genera, species and infra-specific taxa? Diatom Res., 11(1): 203-218.

ROUND, F. E., 1997, Does each diatom genus have a unique feature? Diatom Research, 12(2): 341-345.

ROUND, F. E., CRAWFORD, R. M. \& MANN, D. G., 1990, The diatoms. Biology and morphology of the genera. Cambridge University Press, Cambridge, 747p.

SIMONSEN, R., 1987, Atlas and catalogue of the diatom types of Friedrich Hustedt. J. Cramer, Vaduz, vols. 1 and 3.

VAN LANDINGHAN, S. L., 1975, Catalogue of the fossil and recent genera and species of diatoms and their synonyms. J. Cramer, Vaduz. Part VII, pp. 3606-4241.

WITKOWSKI, A., 1991, Fallacia cassubiae sp. nov., a new brackish-water diatom from the Puck bay (Southern Baltic Sea), Poland. Diatom Res., 6(2): 401-409.

WITKOWSKI, A., 1993, Fallacia florinae (Moeller) comb. nov. a marine, epipsammic diatom. Diatom Res., 8(1): 215-219.

WITKOWSKI, A., LANGE-BERTALOT, H. \& METZELTIN, D., 2000, Diatom flora of marine coasts I. In: H. LangeBertalot (ed.), Iconographia diatomologica. vol. 7, 925p. 